\title{
Non-osseous Calcaneonavicular Coalition in the Portuguese Prehistoric Population: Report of Two Cases
}

\author{
A. M. SILVA* \\ Departamento de Antropologia, Universidade de Coimbra, 3000-056 Coimbra, Portugal
}

ABSTRACT This paper reports articular surface defects detected in three foot bones. These were exhumed from Portuguese collective burial places, Hipogeu de São Paulo II (artificial cave, Almada) and Necrópole da Serra da Roupa (shelter, Columbeira) dated to the Late Neolithic and Chalcolithic periods. Other aetiologies were presented, but non-osseous calcaneonavicular coalition proved to be the most probable explanation for the unusual morphology detected in two calcanei and one navicular bone. Copyright (c) 2005 John Wiley \& Sons, Ltd.

Key words: calcaneonavicular coalitions; collective burials; Late Neolithic/Chalcolithic periods; Portugal

\section{Introduction}

Tarsal coalition represents a bridging between two or more tarsal bones (Vu \& Mehlman, 2002). Although most coalitions are congenital, they can also occur secondary to degenerative joint disease, inflammatory arthritis, trauma, tumour, infection and clubfoot deformities (Percy \& Mann, 1988; Bohne, 2001).

Congenital tarsal coalition may appear isolated or be part of other syndromes: Apert's syndrome, arthrogryposis, and symphalangism, among others (Aufderheide \& Rodríguez-Martín, 1998). These malformations seem to result from abnormal differentiation and segmentation of primitive mesenchyme, with lack of joint formation (Kulik \& Clanton, 1996; Newman \& Newberg, 2000).

Tarsal coalitions are further classified on the basis of the morphology of the bridging between

\footnotetext{
* Correspondence to: Departamento de Antropologia, Universidade de Coimbra, 3000-056 Coimbra, Portugal.

e-mail: amgsilva@antrop.uc.pt
}

Copyright (C) 2005 John Wiley \& Sons, Ltd the adjoining bones: fibrous (syndesmosis), cartilaginous (synchondrosis) or bony (synostosis) union (O'Rahilly 1953; Percy \& Mann, 1988; Kulik \& Clanton 1996; Newman \& Newberg, 2000), or a combination of these (Kulik \& Clanton, 1996). It is noteworthy that in archaeological populations, the medical division between fibrous and cartilaginous coalition is difficult to establish. Therefore, the use of the dichotomy osseous and non-osseous tarsal coalition, as suggested by Regan et al. (1999), seems to be more appropriate. Alternatively, some authors prefer to designate 'coalitions' when bone fusion occurs, and 'bridging' for non-osseous coalitions.

A specific gene mutation as an autosomal dominant inheritance pattern with high or nearly full penetrance seems to be at the origin of these malformations (Plotkin, 1996; Newman \& Newberg, 2000; Scheuer \& Black, 2000; Bohne, 2001; Vu \& Mehlman, 2002).

The real prevalence of tarsal coalition is unknown. Clinical studies suggest that the general incidence in human populations is less than

Received 27 February 2004 Revised 30 December 2004 Accepted 12 January 2005 
$1 \%$ to approximately $1 \%-2 \%$ (Stormont \& Peterson, 1983; Kulik \& Clanton, 1996; Plotkin, 1996; Vincent, 1998; Newman \& Newberg, 2000; Vu \& Mehlman, 2002), although these estimations disregard the asymptomatic coalitions (Ruehli et al., 2002). Clinically, there is a probable slight male predominance and the condition is bilateral in approximately $50 \%$ of the cases of tarsal coalitions (Newman \& Newberg, 2000; Bohne, 2001; Vu \& Mehlman, 2002), although some studies obtained different results (Ruehli et al., 2003). Occasionally, multiple coalitions are found (Newman \& Newberg, 2000; Bohne, 2001; Vu \& Mehlman, 2002).

Theoretically, coalitions can occur between any two contiguous tarsal bones (Scheuer \& Black, 2000; Vu \& Mehlman, 2002). In clinical literature, the most common sites reported are the calcaneonavicular and the talocalcaneal joints (approximately 90\% of the cases) - probably due to the emergence of painful symptoms, such as peroneal spastic flat foot (Stormont \& Peterson, 1983; Kulik \& Clanton, 1996; Newman \& Newberg, 2000; Bohne, 2001)—and less frequently, the talonavicular areas (Stormont \& Petersen, 1983; Percy \& Mann, 1988).

Several recent anthropological papers describe other tarsal defects, like the one between the third metatarsal and third cuneiform, which are clinically less important but apparently more frequent, at least in some human groups (Tenney, 1991; Wilbur, 1997; Regan et al., 1999). However, some authors consider this defect as an anatomical variant (Ruehli et al., 2003).

The onset of symptoms related to tarsal coalition is variable, frequently emerging in the second decade of life. However, in some patients the coalitions may be completely asymptomatic. Symptoms become generally more pronounced with progressive ossification of the coalitions (Keller, 1996). Talocalcaneal coalitions begin to ossify in adolescents aged $12-16$ years, calcaneonavicular coalitions typically ossify between 8-12 years, and talonavicular ones begin to ossify in children aged 3-5 years (Keller, 1996; Newman \& Newberg, 2000; Vu \& Mehlman, 2002). However, it is noted that some coalitions remain non-osseous (Regan et al., 1999; Ruehli et al., 2003).

Copyright (C) 2005 John Wiley \& Sons, Ltd.

\section{Paleopathological evidence}

Despite the rarity of these congenital malformations in palaeopathological contexts, especially non-osseous ones, anatomical descriptions of tarsal coalitions have been known since 1796 (Vu \& Mehlman, 2002).

In 1969, Heiple and Lovejoy confirmed the antiquity of these malformations in the human gene pool by presenting a case of bilateral talocalcaneal bridging in a pre-Columbian Indian specimen. Calder \& Calder (1977, in Anderson, 1995) described a talocalcaneal coalition in an Anglo-Saxon skeleton. In 1995, Anderson published a case of bilateral cubo-navicular bridging (non-osseous), associated with a bilateral metatarsal-cuneiform III defect in an adult male (SK31), exhumed from Iron Age Kent (England).

The aim of this paper is to present two possible cases of non-osseous calcaneonavicular coalitions detected in the human remains exhumed from two Portuguese collective burials dated to the end of the Neolithic/Chalcolithic periods. According to Case (2000), these non-osseous coalitions are recognised in skeletal material when a pair of matching lesions are detected at predictable locations between two adjacent bones.

\section{Presentation of the cases and discussion}

Case 1-Calcaneum and navicular bone from the 'Hipogeu de São Paulo II' (Almada)

In 1989, during repairs in the churchyard of the Old Dominican Convent of São Paulo (16th century) in Almada (Lisbon, Portugal), an artificial cave was discovered. This hypogeum, named São Paulo II, was used as a collective burial place from the end of the Neolithic until the beginning of the Bronze Age, according to the archaeological artefacts. Radiocarbon dating on two human bones gave date ranges of 2905-1950 cal BC (UBAR629) and 2553-2137 cal BC (UBAR - 630) at the (95\% confidence level (Silva, 2002, 2003b).

A total of 19,700 bone or teeth elements were uncovered from this cave built into limestone, which corresponds to a minimum number of 253 individuals (both sexes): 131 adults ( $>15$ years)

Int. J. Osteoarchaeol. 15: 449-453 (2005) 


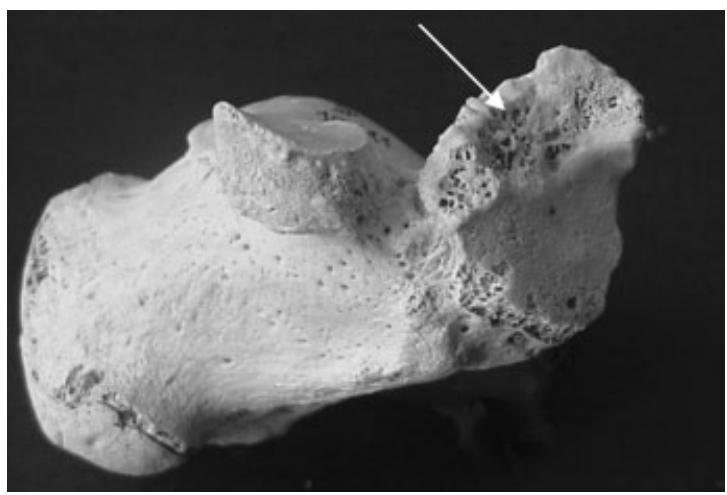

Figure 1. Left juvenile calcaneum recovered from the Hipogeu de São Paulo II, displaying a very irregular border of the anterior talar facet compatible with a case of non-osseous tarsal coalition.

and 123 sub-adults (Silva, 2002, 2003b). Apart from one sub-adult skeleton, all other elements were found disarticulated, due to the burial practice and post-mortuary activities that took place inside the cave. Although fragmentary, the majority of the remains, especially small bones, were well preserved. Among them, two foot bones, a calcaneum and a navicular bone, exhibit an unusual morphology (Silva, 2002).

The left calcaneum $(n=55$ adults; $n=14$ subadults) in question is complete. The epiphysis is almost fused, which indicates an age at death near 18 years (Scheuer \& Black, 2000). The robustness and metrics (Silva, 1995) of this bone suggest a male. The only anomaly recognised is the very irregular border of the anterior talar facet, with some exposure of the internal trabecular bone (Figure 1). The affected area has a long axis of $28 \mathrm{~mm}$ and a mean width of $10 \mathrm{~mm}$. The morphology and location of this unusual morphology is compatible with a case of non-osseous tarsal coalition. A matching lesion was detected in a right navicular $(n=67)$ (Figure 2$)$. The comparable size, and the similar morphology of their articulations, may suggest a possible bilateral case. Nevertheless, the disarticulated nature of their recovery prevents confirmation of this assumption.

\section{Case 2-Calcaneum from 'Necrópole da Serra da Roupa'}

In 1971, three collaborators of the Museu Municipal do Bombarral, Vasco Cortes, Antero

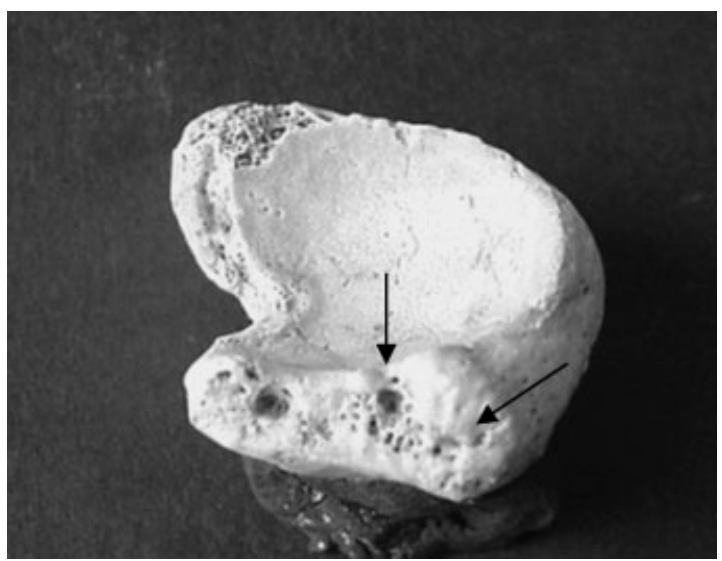

Figure 2. Right navicular bone exhumed from the Hipogeu de São Paulo II, with a similar lesion to the one found on the left calcaneum illustrated in Figure 1.

Furtado and António Maurício, found, during fieldwork near the village of Columbeira, a necropolis on a small limestone massif. The total original area of the platform is unknown, due to extensive destruction by erosion (Silva, 2002, 2003a,b).

Radiocarbon dating of femur fragments indicates a Late Neolithic chronology, $4560 \pm 110$ BP (3626-2917 cal BC, 95\% CI, Sac - 1611). The minimum number of individuals is estimated at 40 (28 adults and 12 sub-adults), including both sexes (Silva, 2002, 2003a,b).

In the calcaneum sample $(n=11)$ an adult right calcaneum $(n=6)$ displays low-grade alterations of the border of the anterior talar facet, with little exposure of the trabecular bone (Figure 3). Although no navicular bone with a similar lesion

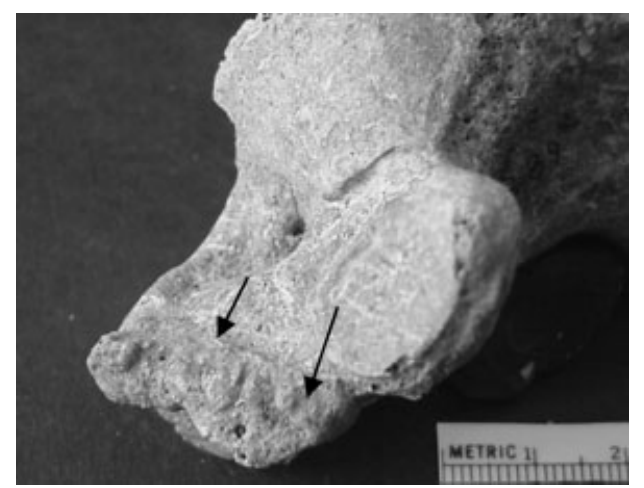

Figure 3. Low-grade alterations of the border of the anterior talar facet of one right calcaneum exhumed from Necrópole Serra da Roupa.

Int. J. Osteoarchaeol. 15: 449-453 (2005) 
was recovered from this shelter, the symmetry of the morphology of these kinds of defects allows its presence to score even if only one of the bones are recovered (Regan et al., 1999).

\section{Differential diagnosis}

Although it is difficult to test differential diagnoses in disarticulated bones, other aetiologies, such as degenerative arthritis, trauma and infection, were considered. Degenerative arthritis is more common in older groups and, at least in the São Paulo II case, the lesion was found in a juvenile. Infection was excluded since no other signs of this pathology, such as periostites, were detected. Trauma is also an unlikely diagnosis since fractures of the calcaneum are rare $( \pm 2 \%$ of all diagnosed fractures according to Burns, 1985), and generally found on only one articular surface. Thus, non-osseous calcaneonavicular coalition appears to be the best diagnosis for the described lesions, since the morphology and location of the described lesions match with the ones found in anthropological and medical literature for this type of congenital malformation.

\section{Conclusion}

This study describes an unusual morphology observed in two calcanei and one navicular bone recovered from two Portuguese collective burials, Hipogeu de São Paulo II (Almada) and Necrópole da Serra da Roupa (Columbeira) dated to the Late Neolithic and Chalcolithic periods. Several other possible aetiologies were considered, but the most probable diagnosis seems to be non-osseous calcaneonavicular coalitions, including one possible bilateral case (São Paulo II). This would confirm the antiquity of this abnormality as described by Heiple \& Lovejoy (1969), and represents the first report of non-osseous tarsal coalition in Portuguese archaeological populations.

\section{Acknowledgements}

I would like to thank the Centro de Investigação em Antropologia for providing financial support for the radiocarbon dating, the Museu Municipal

Copyright (C) 2005 John Wiley \& Sons, Ltd. de Almada and Museu Municipal do Bombarral, where the bones are housed, my colleagues Eugénia Cunha, Sónia Codinha and Teresa Ferreira for commenting on earlier drafts of this paper, and Giles Berillon, Carlos Alberto Ribeiro (Director of Serviço de Cirurgia Maxilo-Facial H.U.C) and José Manuel V. P. Silva (Chefe de Serviço I.P.O.- Coimbra) for their comments. I also thank the manuscript reviewers and Dr Simon Hillson for their helpful comments, and Dr Helen Hartley.

\section{References}

Anderson T. 1995. The Human skeletons. In Iron Age Burials from Mill Hill, Dean, Parfitt K (ed.). British Museum Press: London; 114-144.

Aufderheide A, Rodríguez-Martín C. 1998. The Cambridge Encyclopedia of Human Paleopathology. Cambridge University Press: Cambridge.

Bohne W. 2001. Tarsal coalition. Current Opinions in Pediatrics 13: 29-35.

Burns AE. 1985. Fractures of the calcaneus. Clinical Podiatry 2(2): 311-324.

Case DT. 2000. Developmental defects of the bands and the feet in skeletons from the US and Japan. Poster presented at the XIIth Congress of the European Anthropological Association, 'Millennial Perspectives: Past, Present and Future', Cambridge, 8-11 September.

Heiple KG, Lovejoy CO. 1969. The antiquity of tarsal coalition. Journal of Bone and Joint Surgery-American Volume 51A(5): 979-983.

Keller N. 1996. Wie lautet Ihre Diagnose. Schweizerische Rundschau fuer Medizin (Praxis) 35 Nr. 37: 10991101.

Kulik S, Clanton T. 1996. Tarsal coalition. Foot and Ankle International 17(5): 286-296.

Newman JS, Newberg AH. 2000. Congenital tarsal coalition: multimodality evaluation with emphasis on CT and MR imaging. Radiograpbics 20(2): 321-332.

O'Rahilly R. 1953. A survey of carpal and tarsal anomalies. Journal of Bone and Joint Surgery 35a: 626-642.

Percy E, Mann D. 1988. Tarsal coalition: a review of the literature and presentation of 13 cases. Foot Ankle 9: 40-44.

Plotkin S. 1996. Case presentation of calcaneonavicular coalition in monozygotic twins. Journal of the American Podiatric Medical Association 86(9): 433438.

Regan M, Case DT, Brundige JC. 1999. Articular surface defects in the third metatarsal and third

Int. J. Osteoarchaeol. 15: 449-453 (2005) 
cuneiform: nonosseous tarsal coalition. American Journal of Pbysical Antbropology 109: 53-65.

Ruehli FJ, Solomon LB, Henneberg M. 2003. High prevalence of tarsal coalitions and tarsal joints variants in a recent cadaver sample and its possible significance. Clinical Anatomy 16(5): 411-415.

Scheuer L, Black S. 2000. Developmental Juvenile Osteology. Academic Press: London.

Silva AM. 1995. Sex assessment using calcaneus and talus. Antropologia Portuguesa 13: 85-97.

Silva AM. 2002. Antropologia funerária e Paleobiologia das populaçóes portuguesas (litorais) do Neolítico finall Calcolitico. Unpublished PhD thesis, University of Coimbra (Portugal).

Silva AM. 2003a. A Necrópole da Serra da Roupa: caracterização morfológica, demográfica e patológica de uma população Portuguesa do Neolítico final/Calcolítico. In Preactas y Libro-Guía de la Excursión del III Congreso del Neolítico en la Península Ibérica, Arias P, Ontañón R, García-Moncó Teira L (eds). Santander: 106-107.
Silva AM. 2003b. Portuguese populations of the Late Neolithic and Chalcolithic Periods exhumed from collective burials: an overview. Antbropologie XLI/12: 55-64.

Stormont DM, Peterson HA. 1983. The relative incidence of tarsal coalition. Clinical Orthopaedics $181: 28-36$.

Tenney J. 1991. Comparison of third metatarsal and third cuneiforms defects among various populations. International Journal of Osteoarchaeology 1: 169172.

Vincent K. 1998. Tarsal coalition and painful flatfoot. Journal of the American Academy of Orthopaedic Surgeons 6(5): 274-281.

Vu L, Mehlman DO. 2002. Tarsal coalition. http:// www.emedicine.com7orthoped/topic326.htm.

Wilbur A. 1997. A discrete variant in the third plantar tarsometatarsal joint: patterns of occurrence in a prehistoric population from West-central Illinois. International Journal of Osteoarchaeology 7: 124132. 